\title{
Paleontological Research
}

\section{Papers in Press}

"Papers in Press" includes peer-reviewed, accepted manuscripts of research articles, reviews, and short notes to be published in Paleontological Research. They have not yet been copy edited and/or formatted in the publication style of Paleontological Research. As soon as they are printed, they will be removed from this website. Please note they can be cited using the year of online publication and the DOI, as follows:

Humblet, M. and Iryu, Y. 2014: Pleistocene coral assemblages on Irabu-jima, South Ryukyu Islands, Japan. Paleontological Research, doi: 10.2517/2014PR020. 


\section{Distribution of recent benthic foraminifera off western Costa}

\section{Rica in the eastern equatorial Pacific Ocean}

4

5

6 Hitomi Uchimura ${ }^{\mathrm{a} *}$, Hiroshi Nishi ${ }^{\mathrm{b}}$, Reishi Takashima ${ }^{\mathrm{b}}$, Azumi Kuroyanagi ${ }^{\mathrm{b}}$, Yuzuru

$7 \quad$ Yamamoto $^{\mathrm{c}}$, Steffen Kutterolf ${ }^{\mathrm{d}}$

8

$9{ }^{a}$ Graduate School of Sciences, Tohoku University, 6-3 Aramaki-aza Aoba, Aoba-ku, Sendai,

10 Miyagi, 980-8578, Japan

$11{ }^{b}$ Tohoku University Museum, Tohoku University, 6-3 Aramaki-aza Aoba, Aoba-ku, Sendai,

12 Miyagi, 980-8578, Japan

$13{ }^{c}$ Department of Mathematical Science and Advanced Technology (MAT), JAMSTEC, 3173-

14 25, Showa, Kanazawa-ku, Yokohama, Kanagawa, Japan

$15{ }^{d}$ GEOMAR, Helmholtz-Zentrum für Ozeanforschung Kiel, Wischhofstrasse 1-3, D-24148

16 Kiel, Germany

17

$18 *$ Corresponding author. Graduate School of Sciences, Tohoku University, 6-3 Aramaki-aza

19 Aoba, Aoba-ku, Sendai, Miyagi, 980-8578, Japan

20 Tel.: +81-22-795-6635; Fax: +81-22-795-6634

21 E-mail address: hitomi.bf@gmail.com

22

23 Running title: Recent benthic foraminifera off Costa Rica 


\section{Abstract}

Benthic foraminifera provide essential information for paleobathymetric reconstructions. However, the modern distribution of benthic foraminifera, especially at depths below 1000 mbsl, is still obscure in the offshore regions near Central and South America. To characterize the bathymetric scale in the eastern equatorial Pacific Ocean, we examined the depth distribution of benthic foraminifera using piston core samples taken off the coast of Costa Rica. Foraminiferal assemblages vary according to water depth: 1) U1 (mainly composed of Ammonia beccarii, Cancris sagra, Elphidium tumidum, Hanzawaia concentrica, Pseudononion basispinata, and Planulina exorna) represent inner shelf faunas (shallower than $50 \mathrm{mbsl}$ ). 2) U2 (mainly composed of Ammobacculites foliaceu, Bolivina striatula, Cassidulina minuta, Hanzawaia concentrica, Uvigerina incilis, Bulimina denudata, and Cancris sagra) is correlated with mid shelf depth assemblages, from 50 to 100 mbsl. 3) U3 (mainly composed of Uvigerina incilis, Hanzawaia concentrica, Angulogerina semitrigona, Bolivina acuminata, Bolivina bicostata, and Cibicorbis inflatus) is assigned to outer shelf assemblages from 100 to 200 mbsl. 4) U4 (mainly composed of Bolivina humilis, Bolivina seminuda, Bolivina subadvena, Cassidulina tumida, Epistominella obesa, Angulogerina carinata, and Cibicorbis inflatus) is the upper bathyal faunas (200-600 mbsl). 5) U5 (mainly composed of Brizalina argentea, Uvigerina peregrina, Uvigerina auberiana, Brizalina seminuda, Bulimina striata, Epistominella smithi and Globocassidulina subglobosa) is the mid bathyal faunas (600-1000 mbsl). 6) U6 (mainly composed of Uvigerina auberiana, Uvigerina peregrina, Brizalina argentea, Bulimina mexicana, Cassidulina carinata, Epistominella smithi, and Lenticulina cushmani) represent the lower bathyal assemblage (1000-2000 mbsl). 7) U7 (mainly composed of Uvigerina auberiana, Brizalina argentea, and Eubuliminella tenuata) represent upper abyssal faunas (2000-3000 mbsl). 8) U8 (mainly composed of 
1 Glomospira sp.A, Lagenammina arenulata, Chilostomella oolina, Hoeglundina elegans,

2 Melonis barleeanum, Nonion affine, Oridorsalis umbonatus, Pullenia bulloides, and

3 Uvigerina proboscidea) is characterized by deep-water cosmopolitan faunas (deeper than

$43000 \mathrm{mbsl})$. On the basis of a comparison with several environmental parameters,

5 dissolved oxygen concentrations are likely to be the most effective factor controlling

6 foraminiferal depth distributions in the eastern equatorial Pacific especially the below

7 oxygen minimum zone (OMZ). Around OMZ, nitrate concentration also might be related

8 with the benthic assemblage due to the nitrate respiration.

9

10 Keywords: Benthic foraminifera, Bathymetric scale, Cluster analysis, Recent, Costa Rica

\section{Introduction}

The assemblages of dominant faunas in benthic foraminifera are the most reliable tools for determination of marine bathymetry. These depth distributions of benthic foraminifera enable past depositional depths of sediments to be reconstructed. However, the bathymetric scales of benthic fauna are not always the same in each region. For example, Akimoto and Hasegawa (1988) reported that the seas around the islands of Japan contain different bathymetric distributions of benthic foraminifera, and they proposed three different bathymetric scales for the Pacific Ocean areas off the southwest and the northeast and off the coast of the Japan Sea. Therefore, collecting data on modern distributions of benthic foraminifera from each region is important for bathymetric scale reconstructions.

The Pacific Ocean is the world's largest ocean and is characterized by spatially variable oceanographic conditions, especially between the western and eastern margins. 
1 Warm-water pools exist in the western margin near the equator, whereas relatively cool

2 waters are transported to the eastern margin, where they are associated with upwelling in

3 regions such as the California Current and the Peru Current (Tomczak and Godfrey, 1994).

4 In the eastern Pacific continental margin, most of the foraminiferal studies have been

5 conducted off North America (e.g., Uchio, 1960). The abundance of published reports on

6 this region provides sufficient information for studies on the taxonomic and ecological

7 distribution of benthic foraminifera in the area. However, there are few faunal reports on

8 modern benthic foraminiferal distributions from the regions around the west coasts of

9 South America (e.g. Bandy and Rodolfo, 1964; Ingle et al., 1980; Resig and Glenn, 1997),

10 North America (Uchio, 1960) and over all Central America (Bandy and Arnal, 1957;

11 Heinz et al., 2008). Therefore, more data on modern distributions of benthic foraminifera

12 are needed for bathymetric scale reconstruction based on benthic faunas off Central and

13 South America.

14 Off Central America, previous studies on the modern faunal distributions of benthic

15 foraminifera was conducted on the west coast of Central America (Bandy and Arnal, 1957;

16 Smith, 1963; 1964, Heinz et al., 2008), and in the Gulf of Panama (Golik and Phleger,

17 1977). However, there are very few data especially off Costa Rica despite the tectonic

18 importance of this area (e.g., Ranero and von Huene, 2000; Vannucchi et al., 2004; see

19 following section). For example, Heinz et al. (2008) examined only 7 samples related mud

20 volcanoes, and it could not be enough to construct the depth-scale. Bandy and Arnal

21 (1957) studies also only 5 samples in this area because they focused on an entire region of

22 Central America. Golik and Phleger (1977) investigated an inner bay of Panama,

23 shallower than 200 mbsl, and missed deeper data. Smith (1963; 1964) represented

24 continues data at this area, off Nicaragua, however these studies were also absence of

25 deeper data, especially deeper than 1000 mbsl. 
1 Research cruises by the RV METEOR M54 in 2002 and the RV SONNE in 2003 took box

2 and piston core samples off the Peninsula de Nicoya of Costa Rica in order to examine

3 tectonic system of subduction zone. In this study, we used core-top sediments recovered

4 from selected piston cores taken from these cruises to describe the benthic foraminiferal

5 assemblages in the sediments (Figure 1). We also report bathymetric distributions of

6 benthic foraminifera and propose a bathymetric scale for Central America near Costa Rica.

\section{Materials and methods}

\section{Geological setting}

11 Costa Rica is located at the eastern margin of the Pacific Ocean (Figure 1). This

12 area is a tectonically active zone where the Cocos plate is subducting beneath the

13 Caribbean and North American plates. Erosion related to active subduction occurs from

14 Guatemala to Costa Rica, according to seismic data (Ranero and von Huene, 2000;

15 Vannucchi et al., 2004). The topography of the continental margin here is smooth and is

16 covered by sediments with thicknesses of $0.5-2 \mathrm{~km}$ (Shipley et al., 1992). Within this

17 sedimentary cover, deformed sedimentary prisms are shaped and cut by landward-dipping

18 thrust faults in the middle and lower slope regions of this area.

19 The oceanography around this region is dominated by the Equatorial Undercurrent

20 (EUC), which originates from the southern hemisphere and flows eastward, with one EUC

21 path that flows to the study area (Tomczak and Godfrey, 1994). The strong upwelling of

22 the EUC results in extremely high primary productivity ( $>250 \mathrm{gC} / \mathrm{m}^{2} / \mathrm{yr}$, Couper, 1983)

23 and large benthic biomass $\left(>10 \mathrm{mg} / \mathrm{m}^{2}\right)$. The study area is located east of the Costa Rica

24 Dome, the area of the strongest upwelling off of western Costa Rica located at around $9^{\circ} \mathrm{N}$

25 and $89^{\circ} \mathrm{W}$ (Fiedler and Talley, 2006). The dome is related to the end of the equatorial 
1 current system and mesoscale coastal eddies and produces strong upwelling and a

2 shallowing thermocline (Fiedler and Talley, 2006). To visualize the water-mass structure in

3 this area, we chose six types of data from the NOAA (National Oceanic and Atmospheric

4 Administration) database (https://www.nodc.noaa.gov/OC5/woa13/woa13data.html)

5 (Figure 2). According to these data, the oxygen minimum zone (OMZ) ranges from a 6 depth of $300 \mathrm{~m}$ to $600 \mathrm{~m}$, this relatively shallow depth might be related to the high 7 productivity in this area.

\section{Materials and Laboratory works}

10 To examine the variations in water depth in the western Pacific margin off Costa

11 Rica, we selected 24 GEOMAR piston core samples ranging from a water depth of $54 \mathrm{~m}$

12 to $3535 \mathrm{~m}$ (Figure 1, Table 1). These core samples were obtained from the area off western

13 Central America during the RV METEOR M54 in 2002 and the RV SONNE in 2003

14 cruises. The upper 0-2 cm of each piston core was sampled. The sediment samples were

15 freeze-dried and weighed. Then, they were washed in a 250-mesh sieve (63 $\mu \mathrm{m})$ and dried.

16 The dried fractions $>63 \mu \mathrm{m}$ were reweighed for mud content determination (Figure 3).

17 The samples were divided into aliquots for picking using a microsplitter, and all

18 foraminifera (at least 200 specimens) were picked out. Each specimen was identified and

19 counted for assemblage analysis using taxonomy, according to the method proposed by

20 Loeblich and Tappan (1988). Species diversity of benthic foraminifera was calculated

21 using the Shannon-Weaver index (Shannon and Weaver, 1963) (Figure 3). In addition,

22 numerical foraminiferal parameters (abundance of benthic foraminifera; species richness,

23 which is species number of benthic foraminifera per sample; ratio of planktonic

24 foraminifera to benthic foraminifera; and percentage of hyaline, porcellaneous, and

25 agglutinated benthic foraminifera) were calculated (Figure 3). Additionally, scanning 
1 electron microphotographs (SEM) were taken for selected species (Figure 4, Figure 5).

\section{Statistical analysis}

To determine the dominant assemblage of benthic foraminifera in each sample,

5 cluster analysis (Q-mode) was conducted on the abundances of 24 sediment samples.

6 Similarities between the samples were determined using Horn's index of overlap (Horn,

7 1966), and clustering was performed using the unweighted pair group method with an

8 arithmetic average in a program developed by Davis (1973) and modified by Hasegawa 9 (1988).

Results

\section{Foraminiferal parameters}

14 The abundance of foraminiferal tests ranges from 5 to 16057 individuals per gram

15 of sediment $\left(\mathrm{g}^{-1}\right)$. Specimens with abundances of more than 4000 individuals $\mathrm{g}^{-1}$ are 16 ME54-1 (148 mbsl), ME54-105 (414 mbsl) (Figure 3). Overall species richness is between

$17 \quad 11$ and 48 through the investigated samples, and more than 30 species are recorded at sites

18 ME54-40 (230 mbsl), ME54-63 (815 mbsl), ME-54-92 (1012 mbsl), SO173-81 (2272

19 mbsl), and ME54-57 (3462 mbsl). The maximum value of 48 species occurs at SO173-81

20 (2272 mbsl). In addition, the Shannon-Weaver diversity index was calculated for all 21 samples. The diversity values range from 1.9 to 4.6, with the minimum value recorded at site ME54-64 (750 mbsl) and the maximum at ME54-57 (3462 mbsl) (Figure 3). The

23 species diversity is calculated based on the species richness and equitabilities of the

24 assemblages. The results of species diversity in the study area suggest that the controlling

25 factor may be different at each site. 


\section{Distribution and trend of each species}

In the study area, benthic foraminifera species present significant depth-dependent

4 distributions (Figure 6). To examine foraminiferal habitation, we calculated the relative 5 abundance (\%) and absolute abundance $\left(\mathrm{g}^{-1}\right)$ of each species.

6 Textularia agglutinans exhibit a peak at $54 \mathrm{~m}(7.4 \%)$ and thereafter consistently occur

7 above $750 \mathrm{~m}$ with less than $2 \%$ abundance (Figure 6). Cancris sagra also shows the

8 shallowest habitation. It suggests that the occurrences of these species are characterized by

9 the shallow depth. Uvigerina incilis has two shallow peaks at ME54-68 (54 mbsl; 17.2\%)

10 and ME54-1 (148 mbsl; 22.4\%) and shows less than 5\% abundance at deeper than 148

11 mbsl. Bulimina denudata exhibits a similar trend to Uvigerina incilis. Both Planulina

12 exorna and Brizalina alata also showed the shallow habitation, up to 750 mbsl (Figure 6).

13 Cibicorbis inflatus and Bolivina bicostata represent the maximum value of $13 \%$

14 (148m; 3453 individuals $\left.\mathrm{g}^{-1}\right)$ and 18\% (148m; 4709 individuals $\left.\mathrm{g}^{-1}\right)$, respectively. On the 15 other hand, they show significant low density 3-278 and 3-577 specimens $\mathrm{g}^{-1}$, 16 respectively at other depths, and they do not appear the shallowest site (54 mbsl).

17 Angulogulina carinata are abundant around 230 mbsl. Psedoparrella exigua present the 18 wide range from the shallowest depth (ME54-68; $54 \mathrm{mbsl})$ to the deepest (ME54-56; 3535 19 mbsl) with a prominent peak at 654 mbsl (28\%). They mainly distributed between 400 and 20750 mbsl (more than 10\%), and less abundance at deeper than 2000 mbsl (less than 1\%).

21 Both Epistominella smithi and Epistominella bradyana do not show the significant depth 22 distribution, however, these two species are characteristic distribution, observed only in 23 the eastern Pacific (Smith, 1964).

24 Uvigerina peregrina display distinctive two maxima; 750-1000 mbsl and 1550-1650

25 mbsl with high abundance (more than $15 \%$ ). Globocassidulina subglobosa ranges from 
1654 mbsl to 2272 mbsl, exhibit the relatively high value at 750-1000 mbsl (<5\%), and

2 disappear at deeper than 3000m. Uvigerina auberiana also represent the two peaks (more

3 than 10\%), shallower one is 815-825 mbsl and deeper 1450-1650 mbsl. Brizalina

4 seminuda, Cibicidoides mckannai, and Bulimina mexicana exhibit the similarly trend with

5 relatively wide range distribution. They peaked around 800-1200 mbsl and gradually

6 decrease to deeper depths. On the other hand, Globobulimina affinis do not show

7 continues occurrences. This species display three maximum depths, 1000-1200 mbsl,

$8 \quad 1550-1650$ mbsl, and 3462 mbsl with more than 3\% abundance. Cassidulina carinata

9 shows significant high value between 1200 mbsl (ME54-13) and 1567 mbsl (SO173-98)

10 with 6-15\% relative abundance despite long-range occurrences (148-3535 mbsl).

11 Lenticulina cushmani is also abundant at similar depth, 1447 mbsl (more than 5\%). The

12 shallowest distribution of Eubuliminella tenuata is $654 \mathrm{mbsl}$, however, the peak is 1802

13 mbsl and the abundance is $11.0 \%$.

14 Pullenia bulloides, Melonis barleeanum, and Oridorsalis umbonatus represent 15 relatively deep habitation; peak at 3535 mbsl (8.0\%), 1447 mbsl (3.8\%) to 3535 mbsl 16 (3.5\%), and $\sim 1000 \mathrm{mbsl}(<\sim 2.6 \%)$ to $3462 \mathrm{mbsl}$ (4.9\%), respectively. Uvigerina 17 proboscidea and Glomospira sp.A are observed deeper than 1567 mbsl (SO173-98), and 18 abundant at 3535 mbsl (ME54-56) with 8.0\% relative abundance and at 3462 mbsl 19 (ME54-57) with 5.8\%, respectively. Although Lagenammina arenulata shows a wide 20 distribution, it was abundant at the deeper depth ( 3500 mbsl); relative abundance is less 21 than 2\% at shallower depth of 3462 mbsl (ME54-57), while 11.7\% and 7.1\% at 3462 mbsl and 3535 mbsl (ME54-56), respectively.

\section{Results of the cluster analysis}

25 The Q-mode cluster analysis resulted in the grouping of samples into six main 
1 clusters (Figure 7). We used 24 samples for the analysis with total 120 foraminiferal taxa.

2 In this study, these cluster assemblages are clearly consistent with the depth-distribution

3 results described above. Cluster I is assigned to the shallowest site (54 mbsl). It is

4 characterized by common agglutinated species that compose $16.5 \%$ of the total fauna.

5 Three species, Uvigerina incilis, Pseudononion basispinata, and Cancris sagra, are major

6 calcareous taxa, and their abundances are $17.2 \%, 13.8 \%$, and $11.7 \%$, respectively.

7 Agglutinated foraminifera accounted for approximately 59.3\% of Cluster I.

8 Cluster II comprised two samples (148 mbsl and $414 \mathrm{mbsl}$ ). This cluster contain

9 Uvigerina incilis, Bolivina bicostata, and Cibicorbis inflatus. At 148 mbsl, the abundant

10 species are Uvigerina incilis (22.3\%), Bolivina bicostata (18.0\%), Cibicorbis inflatus

11 (13.2\%), and Brizalina alata (10.4\%), amounting to a total of 53.5\%. At $414 \mathrm{mbsl}$, the

12 species richness is higher (23 species), and the relative abundance of each species is lower

13 than those at 148 mbsl. Brizalina spissa (7.0\%), Bolivina bicostata (7.0\%), and

14 Epistominella bradyana (10.2\%) are abundant species, while Uvigerina incilis decreases

15 to $4.6 \%$ (see Table 2). Foraminiferal shells of this cluster exhibit extremely high abundant

16 value of more than 4000 individuals $\mathrm{g}^{-1}$.

17 Cluster III is composed of three samples; MA54-40 (230 mbsl), ME54-48 (761

18 mbsl), and SO173-110-1 (1006 mbsl). The common and characteristic species of these

19 samples are Bolivina bicostata (1.6\%-7.2\%), Cassidulina tumida (3.2\%-6.8\%),

20 Epistominella bradyana (1.2\%-19.5\%) and Epistominella smithi (1.0\%-1.6\%). Other

21 common occurring species of MA54-40 (230 mbsl) and ME54-48 (761 mbsl) are

22 Cibicorbis inflatus (1.3\%-3.6\%), Angulogerina carinata (0.5\%-5.9\%), and Cancris sagra

23 (1.9\%-2.8\%). MA54-40 (230 mbsl) and SO173-110-1 (1006 mbsl) contain Brizalina

24 spissa. In these species, Bolivina bicostata, Angulogerina carinata, Cibicorbis inflatus and

25 Cancris sagra are the fauna on shelf edge (e.g., Smith, 1963; 1964; Ingle et al., 1980). 
1 Without these shallow species, the rest of the assemblages of ME54-48 (761 mbsl) and

2 SO173-110-1 (1006 mbsl) is huge similar to Cluster IV one (see below). In addition, the

3 common species of ME54-48 (761 mbsl) are Uvigerina peregrina (6.8\%) and Oridorsalis

4 umbonatus (0.5\%), and also SO173-110-1 (1006 mbsl) contains Uvigerina peregrina

5 (7.0\%) and Uvigerina auberiana (2.3\%). Uvigerina peregrina and Uvigerina auberiana

6 are the main species of Cluster IV (see below) and also the typical bathyal fauna (Smith,

7 1963; 1964; Ingle et al., 1980). This facts suggests that MA54-40 (230 mbsl) is an original

8 assemblage, but it is that the assemblage of ME54-48 (761 mbsl) and SO173-110-1 (1006

9 mbsl) contain "reworked-shallow" species. It also suggests this cluster is strongly affected

10 by reworked species, thus we exclude this cluster in the following discussion section.

11 A total of 13 samples (from 654 to 1656 mbsl water depth) are included in Cluster

12 IV. This cluster is divided into two subclusters, IVa (ten samples) and IVb (three samples

13 of ME54-78, SO173-98, and ME54-32), bounded by a similarity of 0.5, which the range is

14 between 1012 and 1447 mbsl. This cluster is characterized by abundant occurrences of the

15 genus Uvigerina. The major species are Uvigerina peregrina in Subcluster IVa and

16 Uvigerina auberiana in Cluster IVb. Other abundantly occurring species are

17 Paracassidulina sp. (5.3\%-12.9\%), Globocasidulina subglobosa (5.6\%-8.6\%), and

18 Bulimina mexicana (5\%-10.4\%). For Subcluster IVa, the common species are Cassidulina

19 tumida (0\%-6.8\%), Bolivina bicostata (7\%-7.2\%), Brizalina spissa (5.4\%-7.0\%).

20 Subcluster IVb includes high abundances of Cassidulina carinata (5.6\%-15.3\%) and

21 Cibicidoides mckannai (6.2\%-11.3\%). In addition, Brizalina species (B. seminuda, 27.8\%;

22 B. semiperforata, 5.4\%; and B. argentea, 5.2\%) also display several peaks within

23 Subcluster IVb.

Cluster V (1802 mbsl and 2272 mbsl, two samples) is also characterized by

25 abundant occurrences of both genera Uvigerina and Brizalina. Abundant species are $U$. 
auberiana (22.0\%-27.0\%), U. peregrina (7.5\%-15.0\%), and U. excellens (9.8\%). Bolivina

2 bicostata (8.6\%), Brizalina argentea (11.0\%), and Eubuliminella tenuata (11.0\%) are also

3 present in relatively high numbers. Other common species are Globobulimina affinis

$4 \quad$ (5.0\%) and Cibicidoides mckannai (5.0\%).

5 Cluster VI comprises deep-water samples (at 3462 mbsl and 3535 mbsl) and is

6 characterized by high species diversity and common occurrences of deep-cosmopolitan

7 fauna such as Pullenia, Oridorsalis, Gyroidina, and Melonis. Agglutinated species account

8 for $24.3 \%$ of this sample, and abundant species are Lagenammina arenulata (7.0\%-

9 11.0\%) and Glomospira spp. (5.8\%). Uvigerina proboscidea and Uvigerina senticosa

10 amount to $8 \%$ and $4 \%$, respectively.

Discussion

\section{Bathymetric model of benthic foraminifera in the Costa Rica region}

On the basis of the results of the faunal and cluster analyses, the distribution of modern benthic foraminiferal assemblages in the study area can be classified into seven assemblages (Table 2). Each cluster and subcluster represents a bathymetric assemblage

18 for each water depth except for Cluster III (including reworked fauna). Clusters I and II

19 are assigned to continental shelf and continental shelf edge faunas at depths shallower than

20414 mbsl. Cluster IV represents assemblages at bathyal depths ranging from 654 to 1802

21 mbsl, and two subclusters (a and b) are bounded by the 1200-1447 m depth, close to the

22 boundary of the upper-middle/lower-middle bathyal depth threshold. Cluster $\mathrm{V}$ is

23 correlated with the lower-middle bathyal assemblages at depths ranging from 1800 to

242272 mbsl. Cluster VI is characterized by deep-water cosmopolitan faunas, which are 25 comparable to a abyssal assemblage, occurring at depths of more than $3462 \mathrm{mbsl}$ in the 
Pacific Ocean.

3 Comparison with previous results for benthic foraminifera off Central America

We recognize the five fauna depending water depth as described above. On the other

5 hand, Smith (1964) distinguished six faunal zones of benthic foraminifera off El Salvador

6 termed as Zone A (0-30 mbsl), B (30-60 mbsl, near the bottom of the thermocline), C

7 (60-150 mbsl, below the thermocline) and three continental slope zones, Zone D (150-

$8600 \mathrm{mbsl}), \mathrm{E}$ (600-1300 mbsl), and F (1300 to $3200 \mathrm{mbsl}$ and over). In order to establish

9 the integrated bathymetric scale, we compared our results with Smith's one (Figure 8). It

10 suggests that the former conducted high-resolution sampling at relatively deeper depth

11 (>500 mbsl), while the latter shallower (<1000 mbsl). Another distribution summary was

12 published by Bandy and Arnal (1957) for the sites in the Central America margin off the

13 Pacific Coast from El Salvador to Costa Rica. Although they examined only 5 sites, these

14 data provide critical information about modern benthic foraminiferal distributions off

15 Central America. Thus based on these results, we proposed the new bathymetric scale off

16 Costa Rica (Figure 8, Table 3). To compile bathymetric scale, bathymetric terminology

17 based on van Morkhoven et al. (1986): inner shelf is 0-50 m, mid shelf is $50-100 \mathrm{~m}$, outer

18 shelf is $100-200 \mathrm{~m}$, upper bathyal is $200-600 \mathrm{~m}$, mid bathyal is $600-1000 \mathrm{~m}$, lower bathyal

19 is $1000-2000 \mathrm{~m}$, upper abyssal is $2000-3000 \mathrm{~m}$, lower abyssal is $3000-6000 \mathrm{~m}$.

21 1) $\mathrm{U} 1$ ( 50 mbsl): Inner shelf zone

Smith (1964) reported that faunal assemblages at shallow depths of less than 20-30

23 mbsl comprise Ammonia beccarii, Elphidium tumidum, and Nonionella (Pseudononion)

24 basispinata in El Salvador. Bandy and Arnal (1957) also reported that porcelaneous

25 species such as Quinqueloculina, Milionella. Hanzawaia nitidula, and Bolivina denudata 
1 are common species. At greater depths $(\sim 50 \mathrm{~m})$ the assemblages become more diverse,

2 comprising Nonionella atlantica (Bandy and Arnal, 1957), Hanzawaia concentrica,

3 Cancris sagra, Planulina exorna, and Bulimina denudata, Textularia panamensis (Smith,

4 1964). Unfortunately, we do not have the less than 50 mbsl data in this study.

5 Smith (1964) divided the zonation into two; one (zone A) is around 0-30 mbsl and

6 the other (zone B) is around 30-50 mbsl. However, we decided that these two zonation

7 could be unified to one zonation (U1) because the component species of the samples in

8 zone A and B are almost same.

9

10 2) U2 (50 100 m): Mid shelf zone

11 From a depth of 50 to 100 mbsl off Central America, the common to abundant

12 species are Hanzawaia nitidula ( 80 mbsl), Bolivina acutula, Discorbis communis, and

13 Uvigerina incilis (Bandy and Arnal, 1957). At El Salvador (64-82 mbsl), the abundant

14 species are Hanzawaia concentrica, Cassidulina minuta, Bolivina striatula. And also

15 Uvigerina incilis, Cancris sagra, and Bulimina denudata are common (Smith. 1964).

In this study, the abundant species are Uvigerina incilis, Ammobacculites foliaceus,

17 Cancris sagra, and Textularia agglutinans (54 mbsl). The shallow buliminid form

18 (Bulimina denudata) and Planulina exorna are also common.

3) U3 (100 200 m): Outer shelf zone

The continental shelf assemblages are slightly different in the two regions. Bolivina acutula (103-110 mbsl), Discorbis panamensis (shallower than $103 \mathrm{mbsl}$ ), and Uvigerina

23 incilis (shallower than 103 mbsl) are common to abundant in Central America (Bandy and

24 Arnal, 1957). At El Salvador (about 140 mbsl), Hanzawaia concentrica, Uvigerina incilis

25 are abundant. In addition, Bolivina interjuncta bicostata, Cancris sagra, Angulogerina 
semitrigona, Bolivina acuminata, and Epistominella bradyana are common (Smith 1964). In this study, ME54-1 (148 mbsl), Uvigerina incilis is still abundant. Other characteristic species are Bolivina bicostata, Brizalina alata, and Cibicorbis inflatus.

4) U4 (200-600 mbsl): Upper bathyal zone

Within the upper bathyal zone, ranging from 200 to $600 \mathrm{mbsl}$, samples were previously taken from a depth of 300-450 mbsl (Bandy and Arnal, 1957; Smith, 1964). These assemblages include abundant Bolivina seminuda, Epistominella bradyana, Epistominella obesa (in Brady and Arnal, 1957) and Bolivina humilis, Bolivina subadvena, Bolivina seminuda, Cassidulina tumida, and Epistominella obesa (Smith, 1964). Angulogerina carinata, Cancris inflatus, and Epistominella bradyana are common. In the site at the edge of the continental shelf (ME-54-4, $230 \mathrm{mbsl}$ ), the benthic assemblage is composed of abundant Cibicorbis inflatus and Epistominella bradyana, with subordinate Angulogerina carinata (this study).

\section{5) U5 (600-1000 m): Mid bathyal zone}

In the middle bathyal, ranging from 600 to $1000 \mathrm{mbsl}$, the abundant species are Epistominella bradyana (shallower than 640 mbsl), Bolivina minuta (shallower than 640 mbsl), Cassidulina delicata (shallower than 777 mbsl), Bolivina spissa (deeper than 822 mbsl), Bolivina tumida (about $822 \mathrm{mbsl}$ ), and Uvigerina peregrina (more than $777 \mathrm{mbsl}$ ) (Bandy and Arnal, 1957). At a depth of $~ 800 \mathrm{~m}$ off El Salvador, Bulimina (Eubuliminella) tenuata (deeper than 800 mbsl), Uvigerina peregrina (deeper than 800 mbsl), Uvigerina excellens (about 800 mbsl), and Bolivina argentea (about 800 mbsl) are commonly observed. The assemblages of the lower-middle bathyal depths (1000-1500 mbsl) are characterized by Bolivina plicata and Uvigerina excellens (deeper than 1025 mbsl) and 
1 Uvigerina proboscidea (Bandy and Arnal, 1957).

2

6) U6 (1000-2000 mbsl): Lower bathyal zone

In the lower middle bathyal (deeper than $1200 \mathrm{mbsl}$ ), the Uvigerina genus (peregrina, proboscedea, and auberiana) is common to abundant, with subordinate amounts of other characteristic species including Epistominella smithi, Cassidulina cushmani and Bulimina (Eubuliminella) tenuata (Smith, 1964).

In this study, from 1200 to 1500 mbsl, Uvigerina peregrina remains a common to abundant species. The abundance of Uvigerina auberiana also increases at $1447 \mathrm{~m}$. Bulimina mexicana and Cassidulina carinata commonly occur. Cibicidoides mckannai and Epistominella bradyana is common. Paracassidulina spp. and Cassidulina carinata have abundances of $5.6 \%-15.3 \%$ at $1200-1447$ mbsl, respectively. Brizalina species (B. semiperforata, B. seminuda, and B. argentea) and Lenticulina cushmani are common. Globobulimina affinis and Chilostomella oolina are recognized as the species associated with oxygen-depleted conditions in modern oceans, but they are very few in number, amounting to less than 3\% at many studied sites. 
7) U7 (2000-3000 m): Upper abyssal zone

In this study, Between 1800 and 3000 mbsl, the assemblages are also characterized

3 by abundant Uvigerina species. The most abundant species is Uvigerina auberiana (more

4 than 20\%). Uvigerina peregrina, Uvigerina proboscedea and Uvigerina excellens is

5 common at 1802 mbsl. Other common species are Bolivina bicostata, Brizalina argentea,

6 and Eubuliminella tenuata at 1802 mbsl. There are no data in Smith (1964) and Bandy and

7 Arnal (1957).

8

9 8) U8 (deeper than 3000 mbsl): Lower abyssal zone

10 In this study, abundant species in this zone are Lagenammina arenulata,

11 Chilostomella oolina and Uvigerina proboscidea are common. The cosmopolitan deep

12 faunas are Melonis barleeanum, Oridorsalis umbonatus, and Pullenia bulloides. However,

13 these species abundances are not high (generally less than 5\%). The high abundances of

14 agglutinated species would be associated with the Calcite compensation depth (CCD)

15 and/or carbonate dissolution, because the depth range of CCD is 3-3.5 $\mathrm{km}$ in the area

16 (Adelseck and Berger, 1975).

17 Off El Salvador, Hoeglundina elegans are common (Smith, 1964). Smith (1964)

18 reported there are living specimen of Pullenia bulloides and Nonion affine.

\section{Environmental factors controlling depth distribution of benthic foraminifera}

21 Bottom-water oxygenation and food availability are the most significant factors

22 determining foraminiferal distributions in the Arabian Sea (e.g., Jannink et al., 1998;

23 Schumacher et al., 2007). Therefore, we examined the relationship between foraminiferal

24 assemblages and environmental parameters (temperature, salinity, dissolved oxygen,

25 phosphate, silicate, and nitrate). The long-term annual mean values of each parameter 
$1 \quad\left(0.5^{\circ}\right.$ latitude-longitude grid data) are available from the NOAA database

2 (https:/www.nodc.noaa.gov/OC5/woa13/woa13data.html), from which we used data for

3 these six factors around our study sites (Figure 2). Dissolved oxygen concentrations

4 display minimum values of $0.05-0.12 \mathrm{ml} \mathrm{L}^{-1}$ at $\sim 400 \mathrm{~m}$. If a value of $0.2 \mathrm{ml} \mathrm{L}^{-1}$ is adopted

5 as a boundary for the OMZ, the OMZ ranges from a depth of $300 \mathrm{mbsl}$ to $600 \mathrm{mbsl}$ and

6 corresponds to Cluster II and IV. The relationships between other Culster were also

7 examined (Table 2). Dissolved oxygen concentrations values were almost same, however,

8 each cluster is constituted by different species. It suggests another environmental factor

9 would control this in addition to the oxygen. Silicate increased constantly with depth

10 despite the OMZ, while the nitrate concentrations rapidly increase at a depth of $\sim 400 \mathrm{mbsl}$

11 near the oxygen minimum value. Recently, nitrate respiration has been observed to be

12 common among foraminifera (e.g. Koho and Pina-Ochoa, 2012). Therefore, the nitrate

13 profiles might be related with the benthic assemblage. However, nitrate respiration in

14 benthic foraminifera is still not well-known (e.g. Koho and Pina-Ochoa, 2012). Further

15 research is required to determine how foraminiferal depth-distributions are related to 16 nitrate and low-oxygen concentrations. Below the OMZ, oxygen concentrations gradually

17 increase toward greater depths up to $>3000 \mathrm{mbsl}$, while temperature, salinity, and

18 phosphate remain at relatively stable values; within $4^{\circ} \mathrm{C}, 0.2,0.3 \mu \mathrm{mol} \mathrm{L}^{-1}$, respectively

19 (Figure 2). Therefore, dissolved oxygen concentrations are likely to be one of the most

20 effective factors controlling foraminiferal depth-distributions, especially below OMZ

21 depth in the eastern equatorial Pacific (Table 2).

\section{Conclusions}

To establish a bathymetric scale for the eastern equatorial Pacific, we investigated 
1 the depth-distribution of benthic foraminifera using piston core sediments. On the basis of

2 the faunal and cluster analyses and results from previous studies, modern benthic

3 foraminifera can be classified into eight bathymetric assemblages: 1) U1 (mainly

4 composed of Ammonia beccarii, Cancris sagra, Elphidium tumidum, Hanzawaia

5 concentrica, Pseudononion basispinata, and Planulina exorna) represent inner shelf

6 faunas (shallower than 50 mbsl). 2) U2 (mainly composed of Ammobacculites foliaceu,

7 Bolivina striatula, Cassidulina minuta, Hanzawaia concentrica, Uvigerina incilis,

8 Bulimina denudata, and Cancris sagra) is correlated with mid shelf depth assemblages,

9 from 50 to 100 mbsl. 3) U3 (mainly composed of Uvigerina incilis Hanzawaia

10 concentrica, Angulogerina semitrigona, Bolivina acuminata, Bolivina bicostata, and

11 Cibicorbis inflatus) is assigned to outer shelf assemblages from 100 to $200 \mathrm{~m}$ depth. 4) U4

12 (mainly composed of Bolivina humilis, Bolivina seminuda, Bolivina subadvena,

13 Cassidulina tumida, Epistominella obesa, Angulogerina carinata, and Cibicorbis inflatus)

14 is the upper bathyal faunas (200-600 mbsl). 5) U5 (mainly composed of Brizalina

15 argentea, Uvigerina peregrina, Uvigerina auberiana, Brizalina seminuda, Bulimina

16 striata, Epistominella smithi and Globocassidulina subglobosa) is the mid bathyal faunas

17 (600-1000 mbsl). 6) U6 (mainly composed of Uvigerina auberiana, Uvigerina peregrina,

18 Brizalina argentea, Bulimina mexicana, Cassidulina carinata, Epistominella smithi, and

19 Lenticulina cushmani) represent the lower bathyal assemblage (1000-2000 mbsl). 7) U7

20 (mainly composed of Uvigerina auberiana, Brizalina argentea, and Eubuliminella

21 tenuata) represent upper abyssal faunas (2000-3000 mbsl). 8) U8 (mainly composed of

22 Glomospira sp.A, Lagenammina arenulata, Chilostomella oolina, Hoeglundina elegans,

23 Melonis barleeanum, Nonion affine, Oridorsalis umbonatus, Pullenia bulloides, and

24 Uvigerina proboscidea) is characterized by deep-water cosmopolitan faunas (deeper than $253000 \mathrm{mbsl})$. 
We also demonstrated a relationship between environmental parameters, such as

2 oxygen concentration. Our results suggest that dissolved oxygen concentrations are one of

3 the most effective factors controlling foraminiferal depth-distributions in the eastern

4 equatorial Pacific especially below oxygen minimum zone (OMZ). Around OMZ, nitrate

5 concentration also might be related with the benthic assemblage due to the nitrate

6 respiration.

\section{Acknowledgements}

We thank Takao Ubukata and two anonymous reviewers for comments to improve

10 the manuscript. We would like to express our sincere appreciation to Shiro Hasegawa

11 (Prof. Emeritus at Kumamoto University) for helpful suggestion. We are also grateful to

12 GEOMAR for providing all the samples required for this study. We appreciate Ken'ichi

13 Ohkushi (Kobe University) for his advice about the taxonomy of Benthic foraminifera. We

14 thank Paola Vannucchi (University of London), Arito Sakaguchi (Yamaguchi University),

15 Kotaro Ujiie (Tsukuba University), Saneatsu Saito (JAMSTEC), and Yoshitaka Hashimoto

16 (Kochi University) for their valuable suggestions on the geology of Costa Rica. We thank

17 Shigeyuki Wakaki (JAMSTEC) for his interactive suggestions. This study was carried out

18 with the support of IODP After Cruise Research Program, JAMSTEC. And it was

19 supported partly by Japan Society for the Promotion of Science, KAKENHI (Grant-in-Aid

20 for Scientific Research) Grant Number 24244082 (to HN) and JP25287130 (to RT). 
2 Adelseck, C. G. and W. H. Berger, 1975: On the dissolution of planktonic foraminifera and associatedmicrofossilsduring settling and on the sea floor. Cushman Foundation for Foraminiferal Research, Special Publication vol. 13, p. 70-81.

5 Akimoto, K. and Hasegawa, S., 1989: Bathymetric distribution of the recent benthic foraminifers around Japan - as a contribution to the new paleobathymetric scale. The Memoir of the Geological Society of Japan, vol. 32, p. 229-240 (in Japanese with English abstract).

9 Bandy, O. L. and Arnal, R. E., 1957: Distribution of recent foraminifera off west coast of 10 Central America. Bulletin of the American Association of Petroleum Geologists, vol. 41, p. 2037-2053.

12 Bandy, O. L. and Rodolfo, K. S., 1964: Distribution of foraminifera and sediments, Peru13 Chile trench area. Deep-Sea Research, vol. 11, p. 817-837.

14 Couper, A., 1983: The Times Atlas of the Oceans, 272 p. New York Van Nostrand 15 Reinhold Co, 1st Edition.

16 Davis, J. C., 1973: Statistics and Data Analysis in Geology, 550 p. John Wiley and Sons, New York.

18 Fiedler, P. C. and Talley, L. D., 2006: Hydrography of the eastern tropical Pacific: a review. Progress in Oceanography, vol. 69, p. 143-180.

20 Golik, A. and Phleger, F. B., 1977: Benthic foraminifera from the Gulf of Panama. Journal of Foraminiferal Research, vol. 7, p. 83-99.

Hasegawa, S., 1988: Distribution of recent foraminferal fauna in Toyama Bay, Central Japan. Revue de Paleobiologie, vol. 2, p. 803-813.

24 Heinz, P., Ruschmeier, W. and Hemleben, C., 2008: Live Benthic foraminiferal assemblages at the Pacific continental margin of Costa Rica and Nicaragua. Journal 
of Foraminiferal Research, vol. 38, p. 215-227.

2 Horn, H., 1966: Measurement of “overlap” in comparative ecological studies. The American Naturalist, vol. 100, p. 419-424.

4 Ingle, J. C., Keller, G. and Kolpack, R. L., 1980: Benthic foraminiferal biofacies, 5 sediments and water masses of the southern Peru-Chile Trench area. $6 \quad$ Micropaleontogy, vol. 26, p. 113-150.

7 Jannink, N. T., Zachariasse, W. J. and Van Der Zwaan, G. J., 1998: Living (Rose Bengal 8 stained) benthic foraminifera from the Pakistan continental margin (northern Arabian 9 Sea). Deep-Sea Research I, v. 45, 1483-1513.

10 Koho, K. A. and Piña-Ochoa, E., 2012: Benthic foraminifera: Inhabitants of low-oxygen 11 environments. Anoxia. Evidence for Eukaryote Survival and Paleontological 12 Strategies, vol. 21, p. 249-285.

13 Loeblich, A. R., Jr. and Tappan, H., 1987: Foraminiferal Genera and There Classification, vols. 1 and 2, 1182 p. Van Nostrand Reinhold Library. Van Nostrand Reinhold 15 Company, New York.

16 Ranero, C. R. and von Huene, R., 2000: Subduction erosion along the Middle America convergent margin, Nature, vol. 404, p. 748-752.

18 Resig, J. M. and Glenn, C. R., 1997: Foraminifera encrusting phosphoritic hardgrounds of the Peruvian upwelling one: taxonomy, geochemistry, and distribution. Journal of Foraminiferal Research, vol. 27, p. 133-150.

21 Schumacher, S., Jorissen, F. J., Dissard, D., Larkin, K. E. and Gooday, A. J., 2007: Live (Rose Bengal stained) and dead benthic foraminifera from the oxygen minimum zone of the Pakistan continental margin (Arabian Sea). Marine Micropaleontology, vol. 62, p.45-73.

25 Shannon, C. E. and Weaver, W., 1963: The Mathematical Theory of Communication. 
University of Illinois Press, Urbana, p. 148.

2 Shipley, T. H., Mcintosh, K. D., Silver, E. A., and Stoffa, P. L., 1992: Three-dimensional imaging of the Costa Rica accretionary prism: structural diversity in a small volume of the lower slope. Journal of Foraminiferal Research, vol. 27, p. 292-300.

5 Smith, P. B., 1963: Recent Foraminifera off Central America. Quantitative and qualitative analysis of the family Bolivinidae. United States Geological Survey Professional Paper 429A, p. 1-39.

8 Smith, P. B., 1964: Recent Foraminifera off Central America. Ecology of benthic species. United States Geological Survey Professional Paper 429B, p. 1-55.

10 Tomczak, M. and Godfrey, J. S., 1994: Regional Oceanography: An Introduction, 422 p, Pergamon Press, Oxford.

12 Uchio, T., 1960: Ecology of living benthonic Foraminifera from the San Diego, California, 13 area. Cushman Foundation For Foraminiferal Research, Special Publication No. 5.

14 Van Morkhoven, F. P. C., Berggren, W. A., and Edwards, A. S., 1986: Cainozoic cosmopolitan deep-water benthic foraminifera. Elf-Aquitaine, 421 p.

16 Vannucchi, P., Galeotti, S., Clift, P. D., Renero, C. R. and von Huene, R., 2004: Longterm subduction-erosion along the Guatemalan margin of the Middle America Trench. Geological Society of America, vol. 32, p. 617-620.

\section{Figure and Table captions}

21 Figure 1. Geological setting and sampling locations for this study.

22 Figure 2. Water column properties: (a) temperature, (b) salinity, (c) dissolved oxygen, (d)

23 silicate, (e) nitrate.

24 Figure 3. Results of the numerical foraminiferal parameters. (a) absolute abundance $\left(\mathrm{g}^{-1}\right)$ 25 as an abundance of benthic foraminifera in individuals per g dry sediment; (b) species 
1 number of benthic foraminifera; (c) species diversity of Benthic foraminifera (H); (d) mud

2 content (\%) as a percentage of dry mud weight (g) per total sample dry weight (g); (e)

3 ratio of planktonic foraminifera to benthic foraminifera (\%); (f) percentages of hyaline,

4 porcellaneous, and agglutinated benthic foraminifera (\%).

5 Figure 4. Scanning electron micrographs of benthic foraminifera in this study. 1,

6 Ammobaculites foliaceus (Brady); 2, Textularia agglutinans (d'Orbigny); 3, Lagenammina

7 arenulata (Skinner) ; 4, Bulimina denudata (Cushman and Parker); 5, Bulimina

8 striata (d'Orbigny in Guérin-Méneville); 6, Bolivina bicostata (Cushman); 7, Uvigerina

9 incilis (Todd); 8, Uvigerina proboscidea (Schwager); 9, Uvigerina peregrina (Cushman);

10 10, Angulogerina carinata (Cushman); 11,Cibicorbis inflatus (Cushman); 12,

11 Ehrenbergina pupa (d'Orbigny) 13, Pseudononion basispinata (Cushman and Moyer) 14,

12 Cancris sagra (d'Orbigny). Scale bars are $100 \mu \mathrm{m}$.

13 Figure 5. Scanning electron micrographs of benthic foraminifera in this study. 1,

14 Epistominella bradyana (Cushman); 2, Cassidulina carinata (Silvestri); 3, Epistominella

15 smithi (R.E. \& K.C. Stewart); 4, Gyroidina soldanii (d'Orbigny); 5, Eubuliminella tenuata

16 (Cushman); 6, Globocassidulina subglobosa (Brady); 7, Pullenia bulloides (d'Orbigny) ; 8,

17 Melonis barleeanus (Williamson, 1858); 9, Oridorsalis umbonatus (Reuss); 10, Planulina

18 exorna (Phleger and Parker). Scale bars are $100 \mu \mathrm{m}$.

19 Figure 6. Relative abundances of the significant species in benthic foraminifera in 20 different zones off the Pacific Coast of Western Costa Rica.

$21 \quad$ Figure 7. Results of the cluster analyses.

22 Figure 8. Compiled range chart of the results of Smith (1964) and this study.

24 Table 1. Distributions for each sample. ME54 samples were taken by the cruise of the RV 25 METEOR M54 in 2002, and also SO173 samples were taken by the cruise of the RV 
1 SONNE in 2003.

2 Table 2. Features of cluster I - VI with Dissolved oxygen value.

3 Table 3. Integrated bathymetric scale off western Costa Rica. The species of the circles are 4 abundant. 


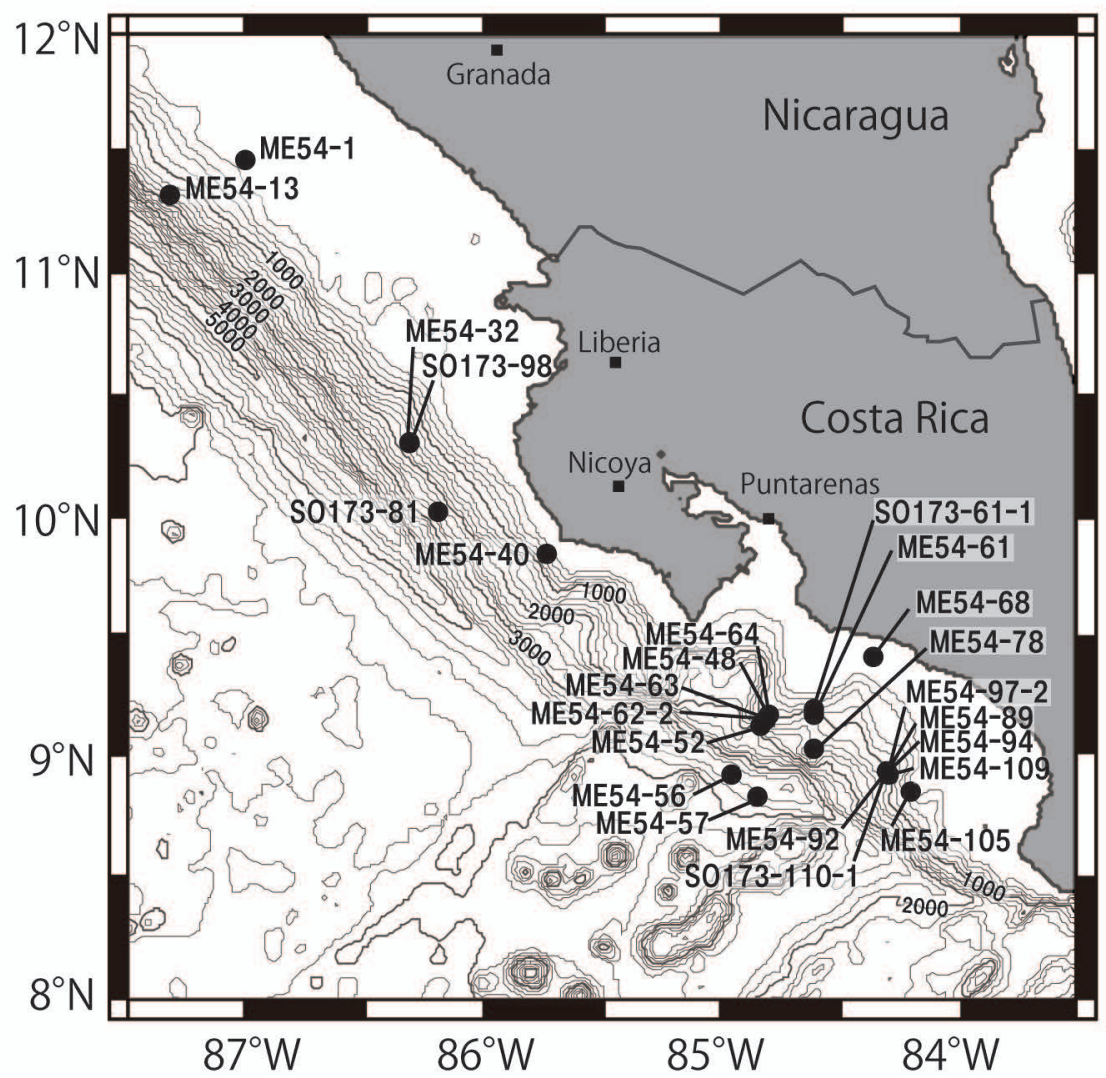



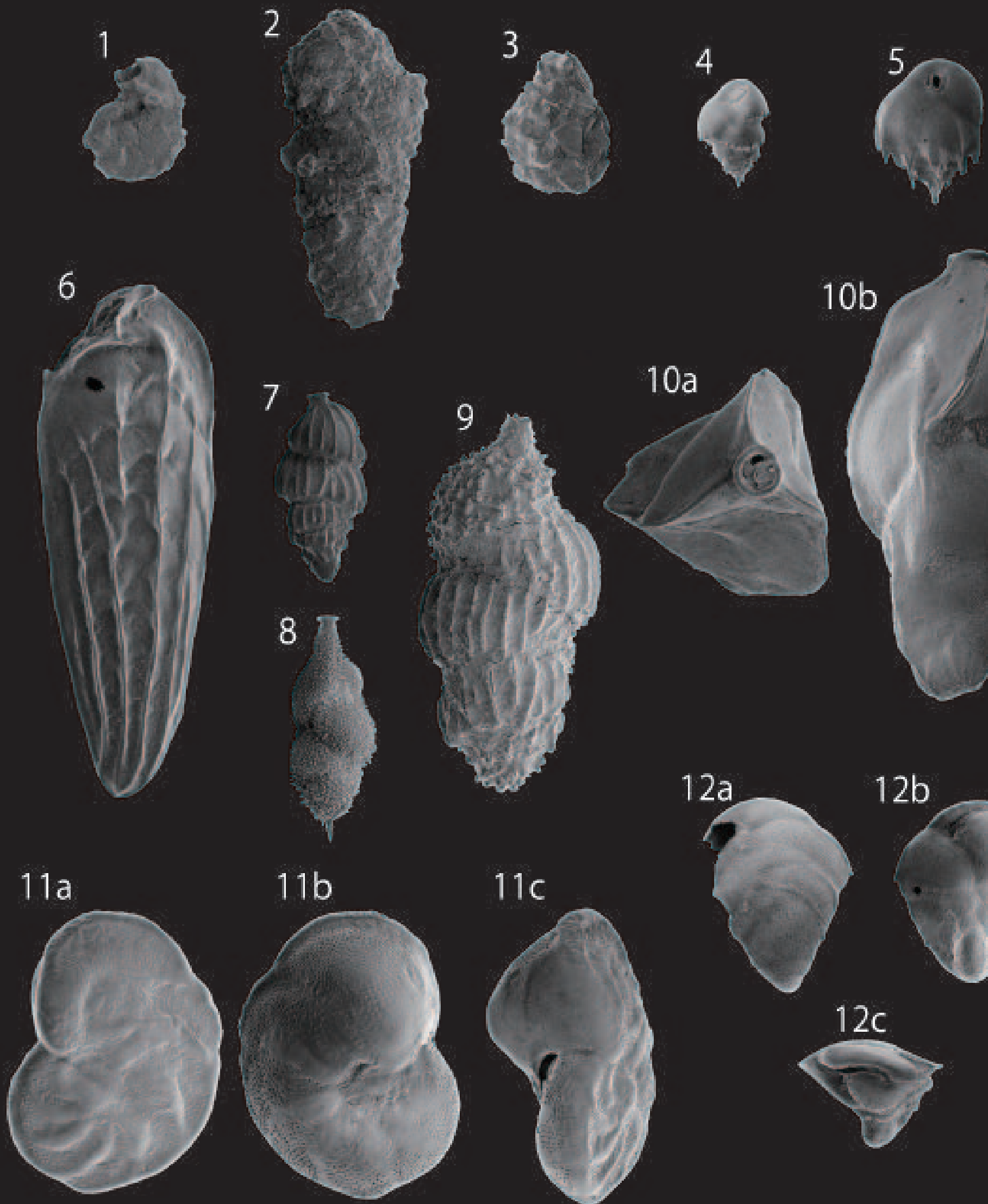

$11 c$
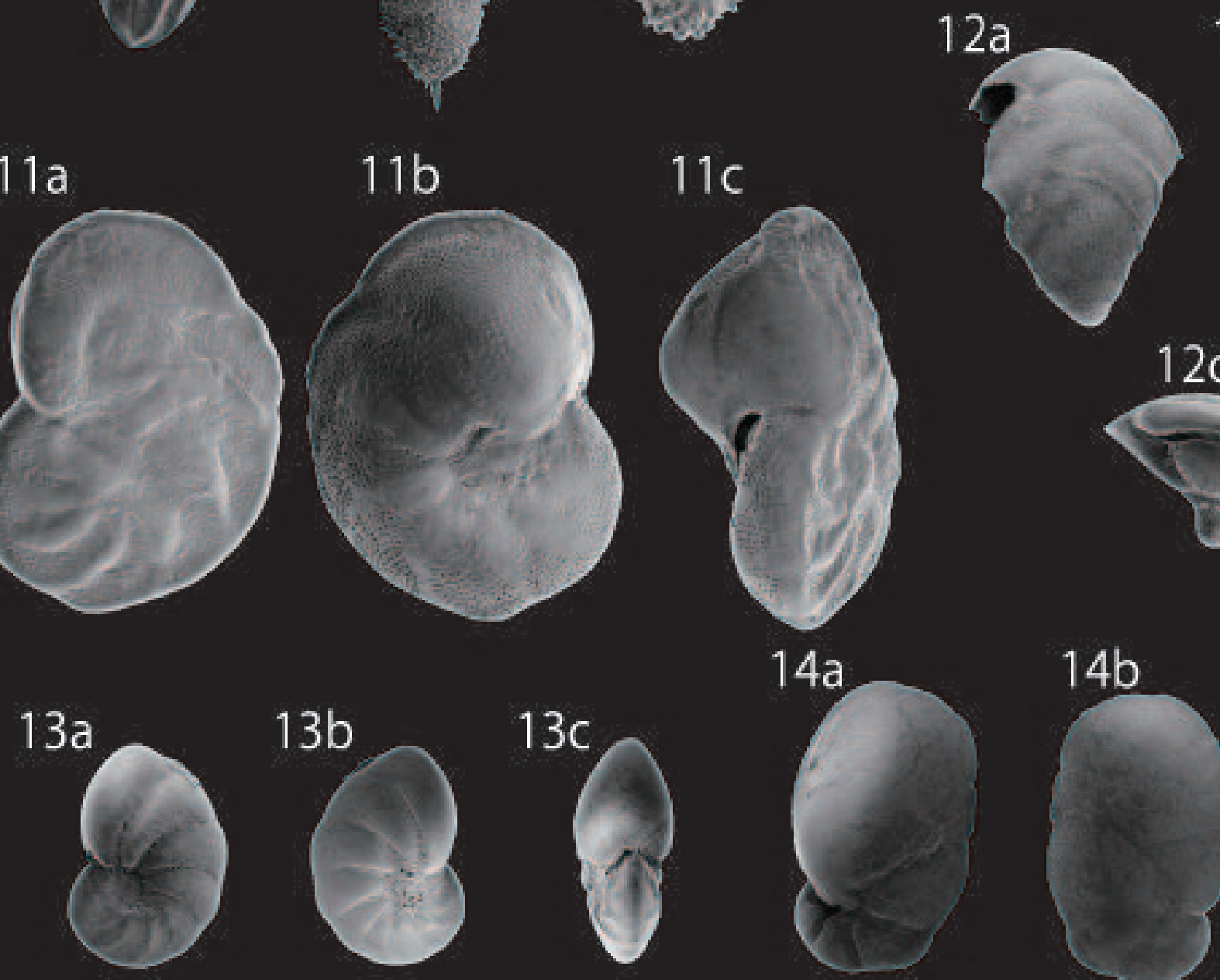

$12 b$
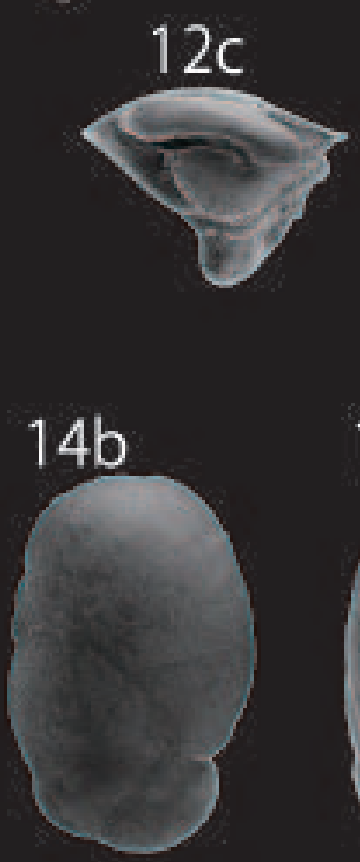

$14 c$

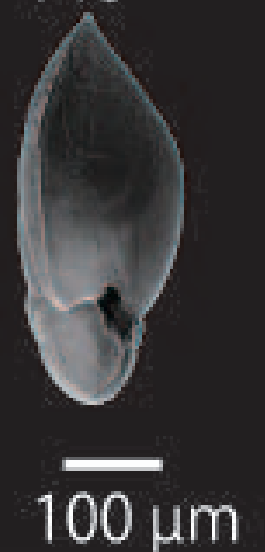



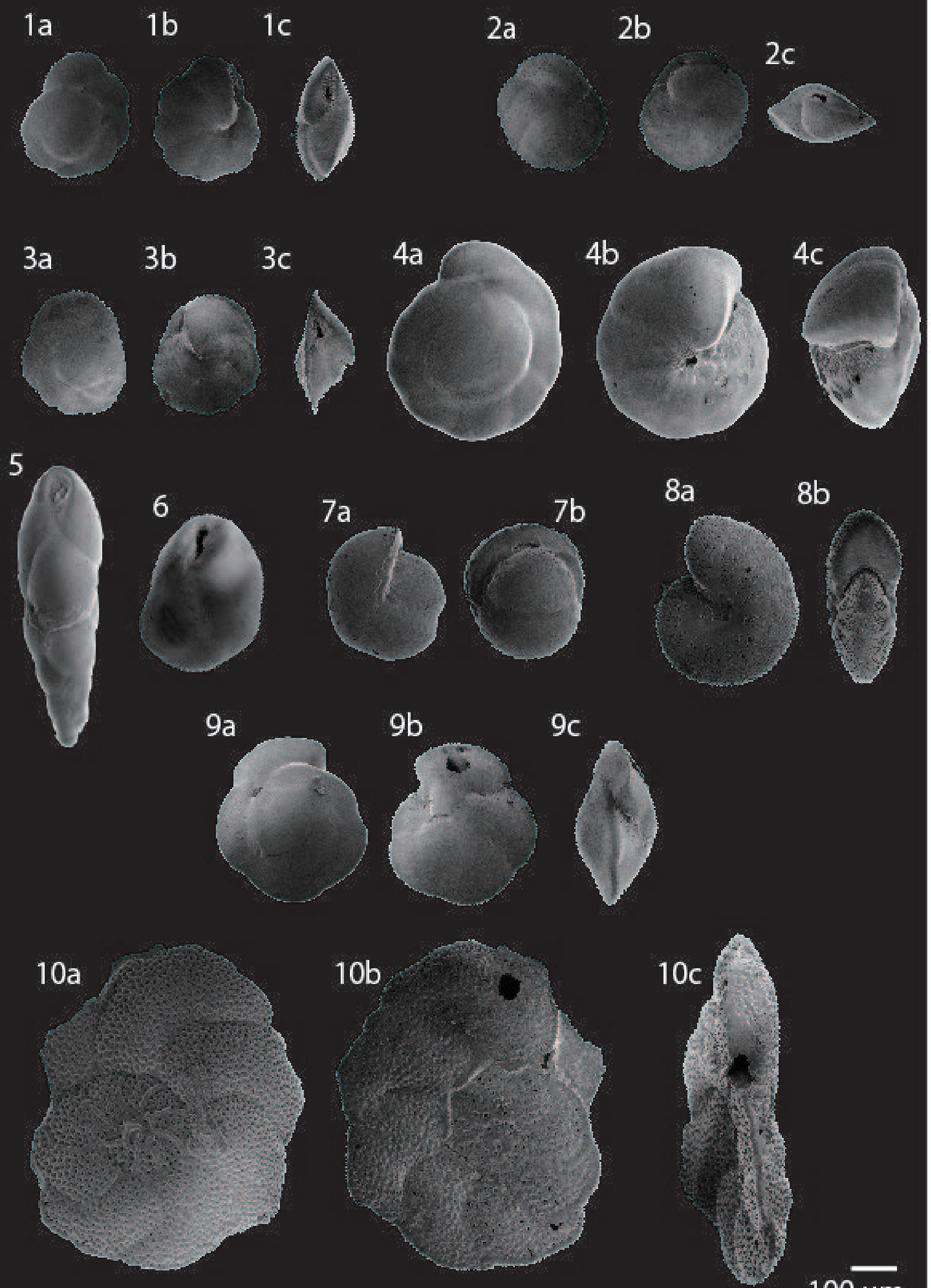


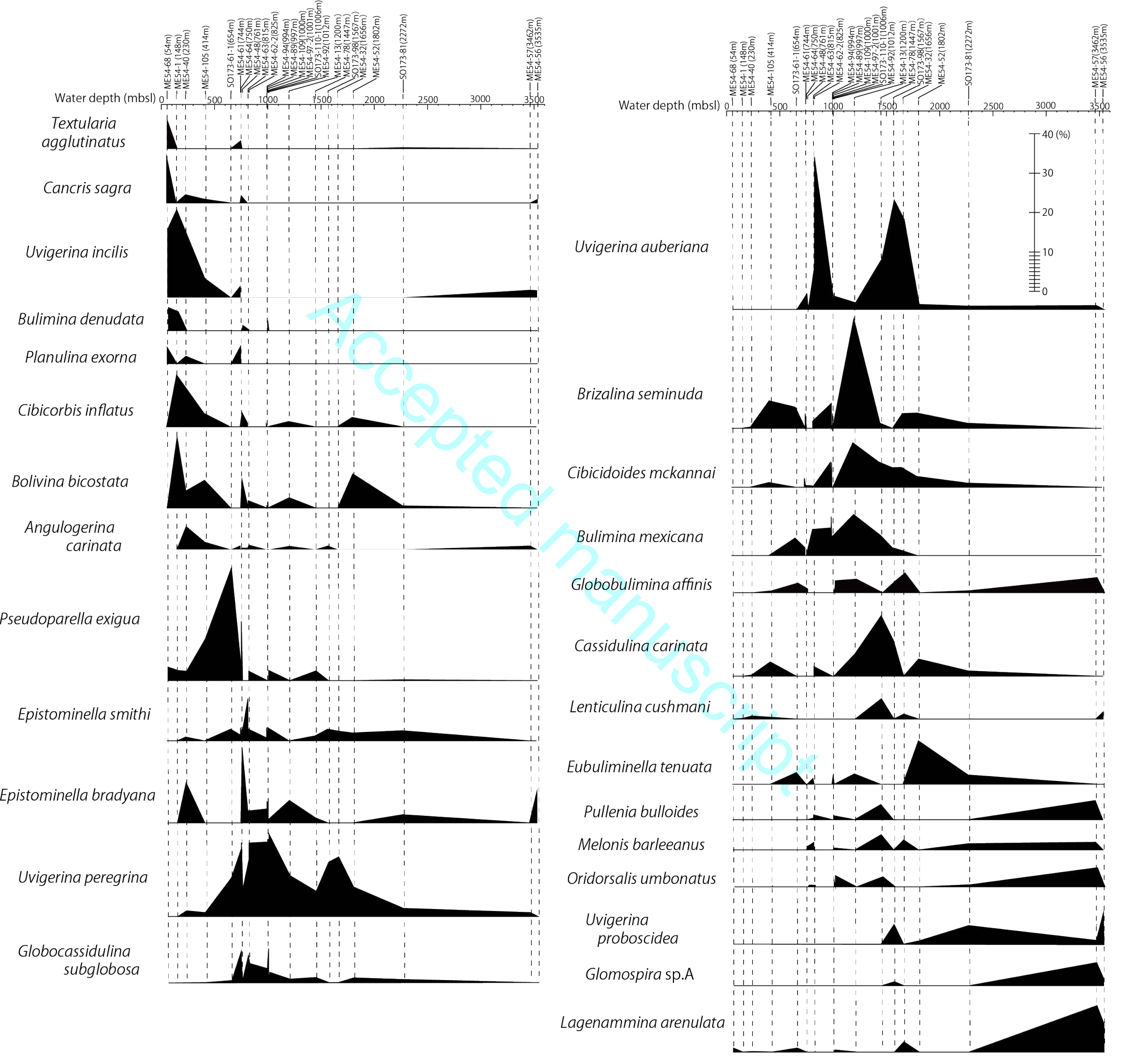




\section{Similality}

Assemblage

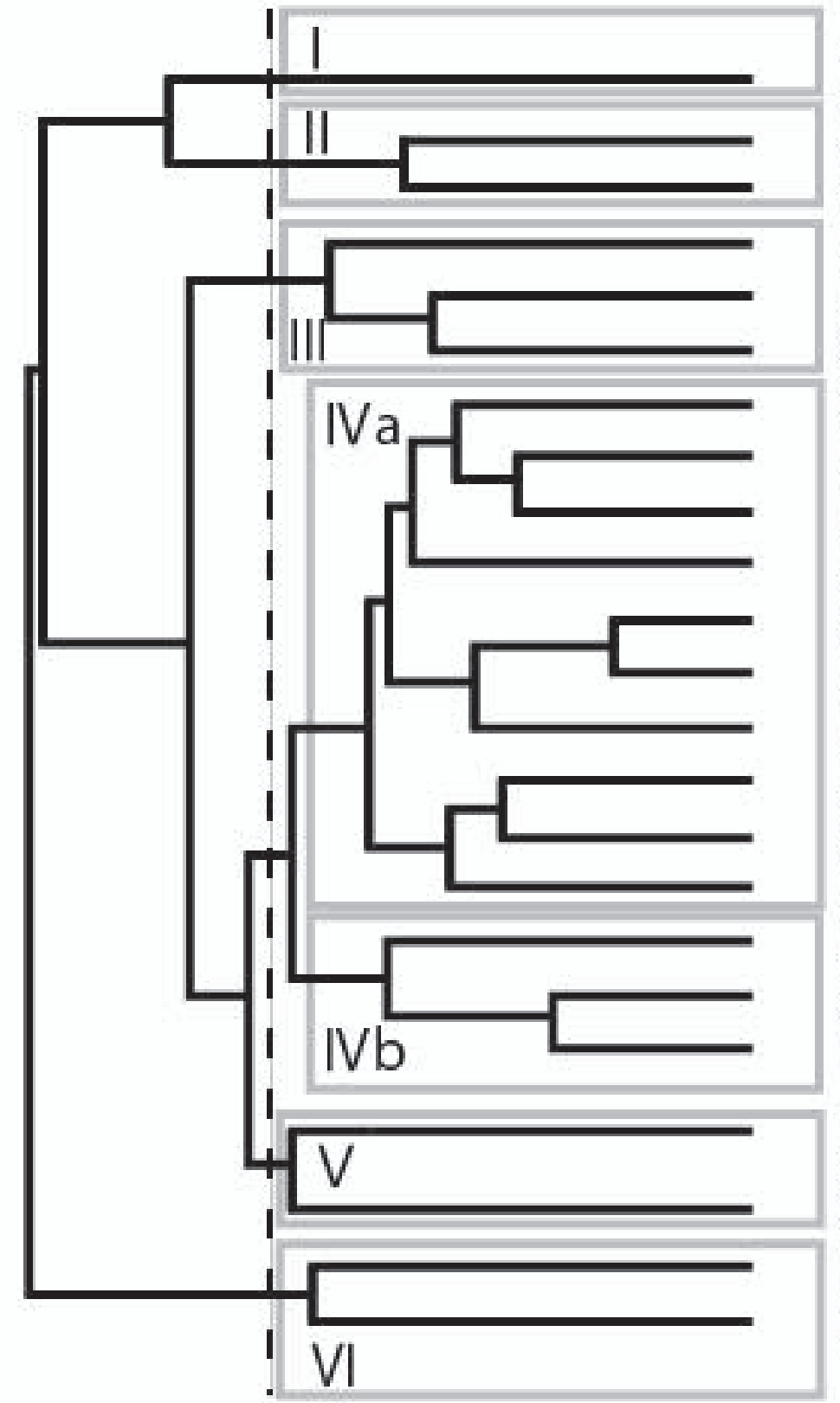

ME54-68 (54m)

ME54-1 (148m)

ME54-105 (414m)

ME54-40 (230m)

ME54-48 (761 m)

S0173-110-1 (1006m)

S0173-61-1 (654m)

ME54-61 (744m)

ME54-92 (1012m)

ME54-64 (750m)

ME54-94 (994m)

ME54-97-2 (1001m)

ME54-89 (997m)

ME54-63 (815m)

ME54-62-2 (825m)

ME54-109 (1000m)

ME54-78 (1447m)

S0173-98 (1567m)

ME54-32 (1656m)

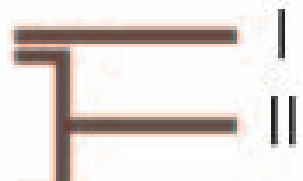

$=$

ME54-52 (1802m)

SO173-81 (2272m)

ME54-57 (3462m)

ME54-56 (3535m)

IVa

$\mathrm{IVb}$ 
Smith (1964)

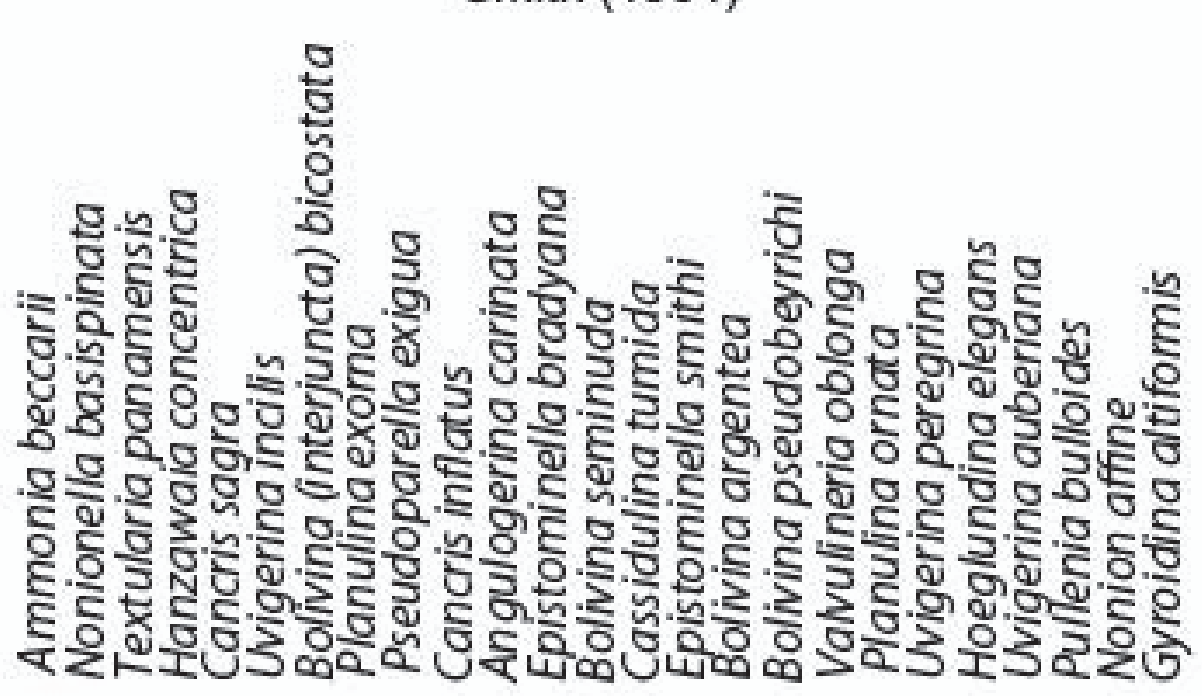

TT+atitito
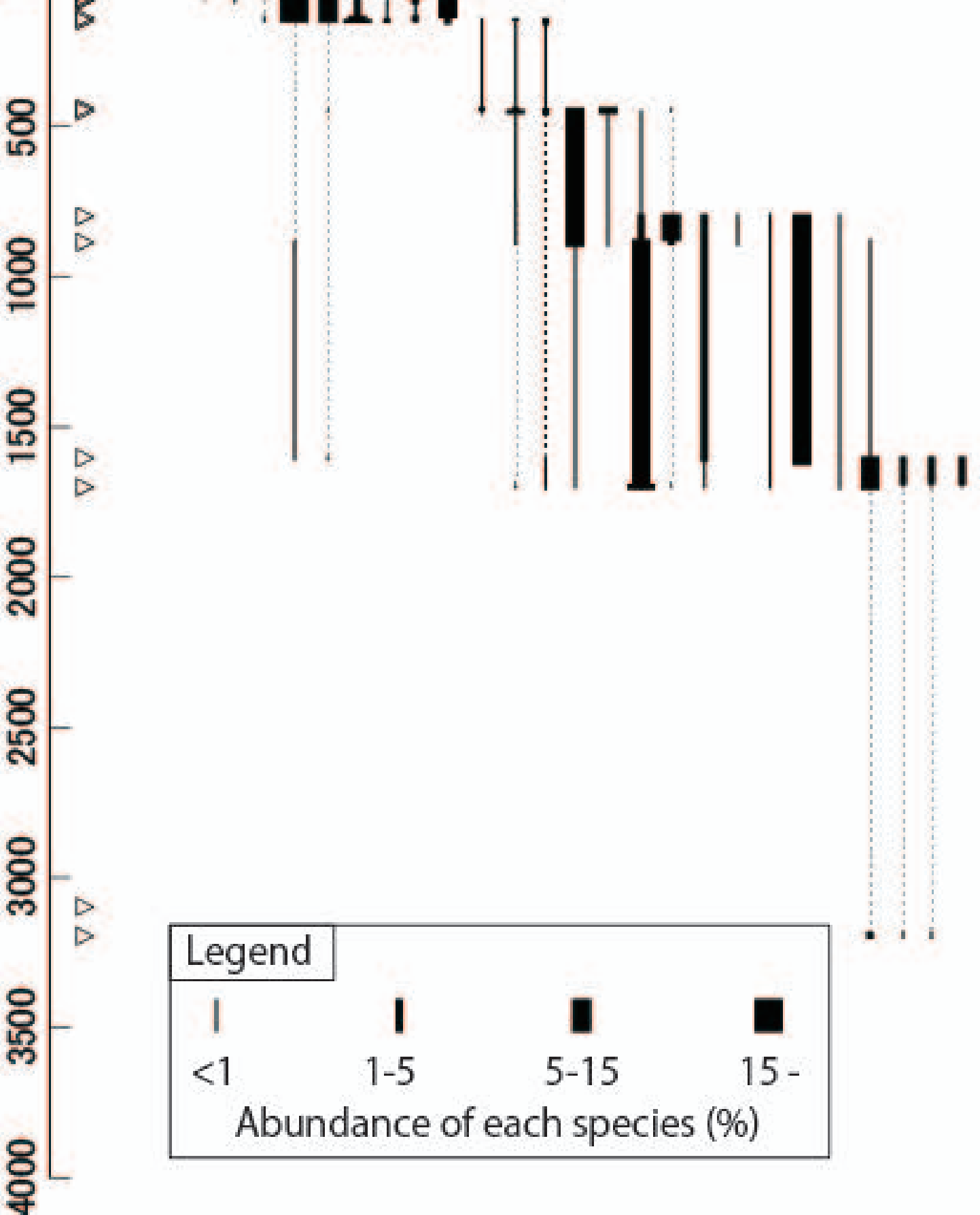

Uchimura et al. (This study)
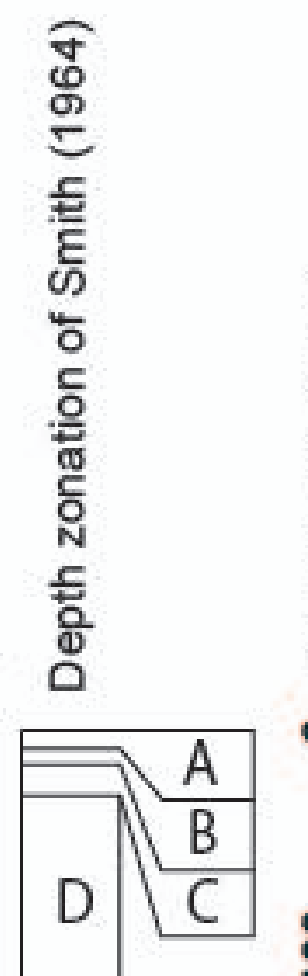

E

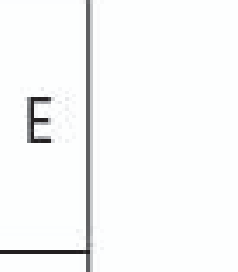

8 .

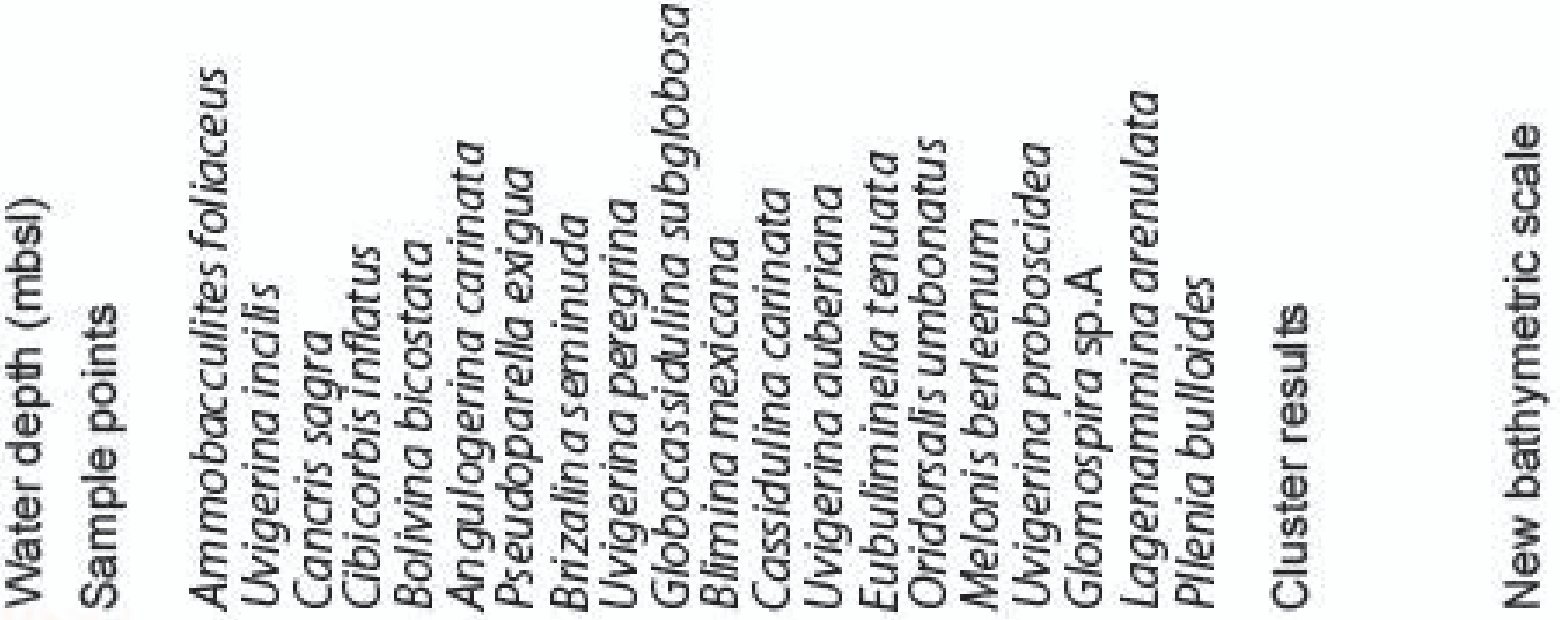

:

ะू.

F

율

ठ্्.

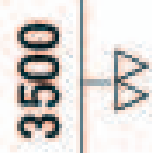

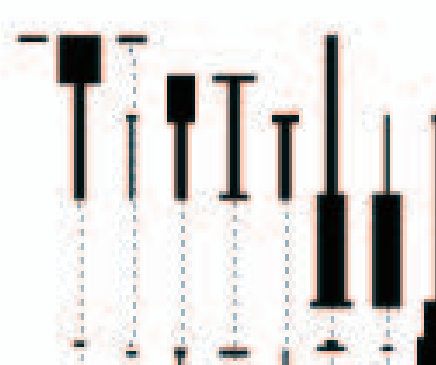

$\ldots$

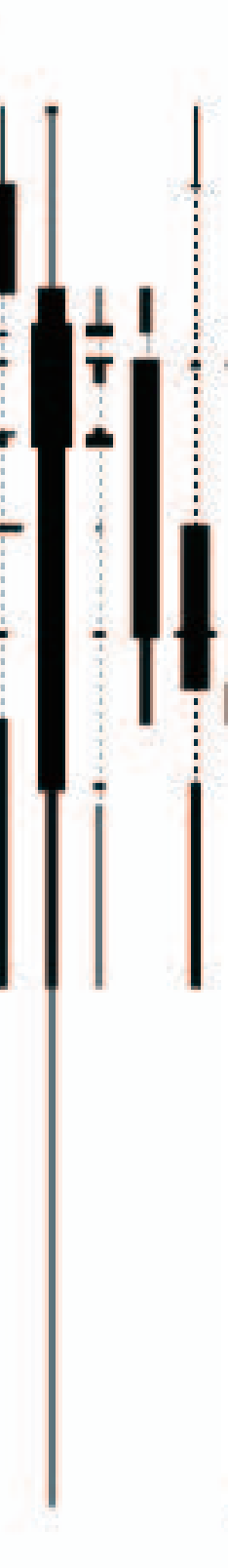

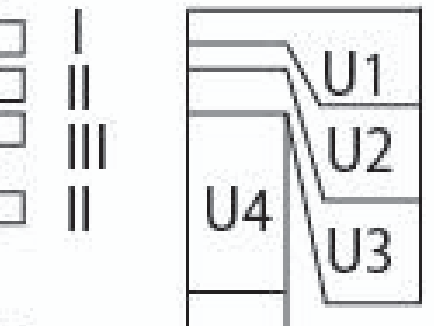

I $\quad \ldots \quad$ Vl-a U5

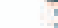

. . . Vl-b

U6

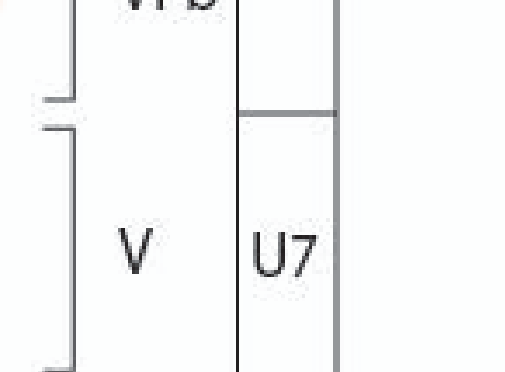

8 
Table 1

\begin{tabular}{lccc}
\hline \multicolumn{1}{c}{ Station } & $\begin{array}{c}\text { Nater depth } \\
(\mathrm{m})\end{array}$ & $\begin{array}{c}\text { Latitude } \\
\left(\mathrm{N}^{\circ}\right)\end{array}$ & $\begin{array}{c}\text { Longitude } \\
\left(\mathrm{W}^{\circ}\right)\end{array}$ \\
\hline ME54-68 & 54 & $09^{\circ} 24.71^{\prime}$ & $84^{\circ} 22.51^{\prime}$ \\
ME54-1 & 148 & $11^{\circ} 28.91^{\prime}$ & $87^{\circ} 00.02^{\prime}$ \\
ME54-40 & 230 & $09^{\circ} 50.27^{\prime}$ & $85^{\circ} 44.07^{\prime}$ \\
ME54-105 & 414 & $08^{\circ} 51.20^{\prime}$ & $84^{\circ} 13.01^{\prime}$ \\
SO173-61-1 & 654 & $09^{\circ} 12.00^{\prime}$ & $84^{\circ} 37.24^{\prime}$ \\
ME54-61 & 744 & $09^{\circ} 10.46^{\prime}$ & $84^{\circ} 47.76^{\prime}$ \\
ME54-64 & 750 & $09^{\circ} 10.54^{\prime}$ & $84^{\circ} 48.27^{\prime}$ \\
ME54-48 & 761 & $09^{\circ} 10.41^{\prime}$ & $84^{\circ} 48.25^{\prime}$ \\
ME54-63 & 815 & $09^{\circ} 09.11^{\prime}$ & $84^{\circ} 49.28^{\prime}$ \\
ME54-62-2 & 825 & $09^{\circ} 09.02^{\prime}$ & $84^{\circ} 49.18^{\prime}$ \\
ME54-94 & 994 & $08^{\circ} 55.81^{\prime}$ & $84^{\circ} 18.64^{\prime}$ \\
ME54-89 & 997 & $08^{\circ} 55.89^{\prime}$ & $84^{\circ} 18.69^{\prime}$ \\
ME54-109 & 1000 & $08^{\circ} 55.31^{\prime}$ & $84^{\circ} 18.26^{\prime}$ \\
ME54-97-2 & 1001 & $08^{\circ} 55.90^{\prime}$ & $84^{\circ} 18.70^{\prime}$ \\
SO173-110-1 & 1006 & $08^{\circ} 55.74^{\prime}$ & $84^{\circ} 18.81^{\prime}$ \\
ME54-92 & 1012 & $08^{\circ} 55.88^{\prime}$ & $84^{\circ} 18.77^{\prime}$ \\
ME54-13 & 1200 & $11^{\circ} 20.12^{\prime}$ & $87^{\circ} 18.30^{\prime}$ \\
ME54-78 & 1447 & $09^{\circ} 02.01^{\prime}$ & $84^{\circ} 37.25^{\prime}$ \\
SO173-98 & 1567 & $10^{\circ} 17.79^{\prime}$ & $86^{\circ} 18.59^{\prime}$ \\
ME54-32 & 1656 & $1^{\circ} 18.06^{\prime}$ & $86^{\circ} 18.55^{\prime}$ \\
ME54-52 & 1802 & $09^{\circ} 07.23^{\prime}$ & $84^{\circ} 50.65^{\prime}$ \\
SO173-81 & 2272 & $10^{\circ} 00.51^{\prime}$ & $86^{\circ} 11.39^{\prime}$ \\
ME54-57 & 3462 & $08^{\circ} 49.70^{\prime}$ & $84^{\circ} 51.21^{\prime}$ \\
ME54-56 & 3535 & $08^{\circ} 55.61^{\prime}$ & $84^{\circ} 58.01^{\prime}$ \\
\hline
\end{tabular}


$\underline{\text { Table 2. Features of cluster I - VI with Dissolved oxygen value. }}$

\begin{tabular}{|c|c|c|c|c|c|c|c|}
\hline \multirow{2}{*}{ Cluster } & \multirow[b]{2}{*}{ I } & \multirow{2}{*}{ II } & \multirow{2}{*}{ III } & \multicolumn{2}{|l|}{ IV } & \multirow{2}{*}{ V } & \multirow{2}{*}{ VI } \\
\hline & & & & $\mathrm{a}$ & $\mathrm{b}$ & & \\
\hline $\begin{array}{c}\text { Water depth } \\
\text { (mbsl) }\end{array}$ & 54 & 148,414 & $230,761,1006$ & $654-1012$ & $1447-1802$ & $1802-2272$ & $3462 \sim$ \\
\hline \multirow{5}{*}{ Major species } & Ammobacculites foliaceus & Uvigerina incilis & Epistominella bradyana & Uvigerina peregrina & Uvigerina auberiana & Uvigerina auberiana & Oridorisalis umbonatus \\
\hline & Textularia agglutinans & Brizalina bicostata & Cassidulina tumida & Globocassidulina subglobosa & Uvigerina peregrina & Uvigerina peregrina & Pullenia bulloides \\
\hline & Uvigerina incilis & Cibicorbis inflatus & Epistominella smithi & Bulimina mexicana & Cassidulina carinata & Uvigerina excellens & Melonis barleeanus \\
\hline & Pseudononion basispinata & Brizalina alata & Brizalina bicostata & Cassidulina tumida & Cibicidoides mckannai & Brizalina argentea & Lagenammina arenulatc \\
\hline & Cancris sagra & Epistominella bradyana & & Uvigerina auberiana & & Eubuliminella tenuata & Uvigerina proboscidea \\
\hline $\begin{array}{c}\text { Dissolved } \\
\text { oxygen } \\
\text { (ml/L) }\end{array}$ & $1.2-1.4$ & $0.1-0.5$ & $0.3-0.7$ & $0.2-0.8$ & $1.4-1.7$ & $1.9-2.4$ & $\sim 2.6$ \\
\hline
\end{tabular}


Table 3. Integrated bathymetric scale off western Costa Rica. The species of the circles are abundant.

\begin{tabular}{|c|c|c|c|c|c|c|c|c|}
\hline Unit name & U1 & $\mathrm{U} 2$ & U3 & $\mathrm{U} 4$ & $\mathrm{U} 5$ & U6 & $\mathrm{U} 7$ & U8 \\
\hline \begin{tabular}{|c|}
$\begin{array}{c}\text { Bathymetric zone } \\
(\mathrm{mbsl})\end{array}$ \\
\end{tabular} & $\begin{array}{c}\text { Inner shelf } \\
0-50\end{array}$ & $\begin{array}{l}\text { Mid shelf } \\
50-100\end{array}$ & $\begin{array}{c}\text { Outer shelf } \\
100-200\end{array}$ & $\begin{array}{c}\text { Upper bathyal } \\
200-600\end{array}$ & $\begin{array}{c}\text { Mid bathyal } \\
600-1000\end{array}$ & $\begin{array}{c}\text { Lower bathyal } \\
1000-2000\end{array}$ & $\begin{array}{l}\text { Upper abyssal } \\
2000-3000\end{array}$ & $\begin{array}{c}\text { Lower abyssal } \\
3000-\end{array}$ \\
\hline Main species & $\begin{array}{l}\text { ○ Ammonia beccarii } \\
\bigcirc \text { Cancris sagra } \\
\bigcirc \text { Elphidium tumidum } \\
\bigcirc \text { Hanzawaia concentrica } \\
\bigcirc \text { Pseudononion basispinata } \\
\text { Bulimina denudata } \\
\text { Planulina exorna } \\
\text { Textularia panamensis }\end{array}$ & $\begin{array}{l}\text { ○ Ammobacculites foliaces } \\
\bigcirc \text { Bolivina striatula } \\
\text { ○ Cassidulina minuta } \\
\text { ○ Hanzawaia concentrica } \\
\text { ○ Uvigerina incilis } \\
\text { Bulimina denudata } \\
\text { Cancris sagra } \\
\text { Planulina exorna } \\
\text { Textularia agglutinans }\end{array}$ & $\begin{array}{l}\text { O Uvigerina incilis } \\
\text { O Hanzawaia concentrica } \\
\text { Bolivina (interjunctata bicostata } \\
\text { Angulagerina semitrigona } \\
\text { Bolivina acuminata } \\
\text { Brizalina alata } \\
\text { Cancris sagra } \\
\text { Cibicorbis inflatus } \\
\text { Epistominella bradyana }\end{array}$ & $\begin{array}{l}\text { O Bolivina humilis } \\
\text { ○ Bolivina seminuda } \\
\text { ○ Bolivina subadvena } \\
\text { O Cassidulina tumida } \\
\bigcirc \text { Epistominella obesa } \\
\text { Angulogerina carinata } \\
\text { Cibicorisi inflaus } \\
\text { Epistominella bradyana }\end{array}$ & $\begin{array}{l}\text { O Brizalina argentea } \\
\text { ○ Uvigerina peregrina } \\
\text { Uvigerina auberiana } \\
\text { Brizaliana aseminuda } \\
\text { Bulimina striata } \\
\text { Epistominella bradyana } \\
\text { Epistominella smithi } \\
\text { Globocassidulina subglobosa } \\
\text { Psedoparrella exigua }\end{array}$ & $\begin{array}{l}\text { O Uvigerina auberiana } \\
\text { O Uvigerina peregrina } \\
\text { Brizalina argentea } \\
\text { Bulimina mexicana } \\
\text { Cassidulina carinata } \\
\text { Cibicidoides mckannai } \\
\text { Epistominella bradyana } \\
\text { Epistominella smithi } \\
\text { Lenticulina cushmani }\end{array}$ & $\begin{array}{l}\text { O Uvigerina auberiana } \\
\text { Brizalina argentea } \\
\text { Cibicidoides mckannai } \\
\text { Eubuliminella tenuata } \\
\text { Globobulimina affinis } \\
\text { Uvigerina excellens } \\
\text { Uvigerina peregrina } \\
\text { Uvigerina proboscedea }\end{array}$ & $\begin{array}{l}\text { O Glomospira sp.A } \\
\text { O Lagenammina arenulata } \\
\text { Chilostomella oolina } \\
\text { Hoeglundina elegans } \\
\text { Melonis barleeanus } \\
\text { Nonion affine } \\
\text { Oridorsalis umbonatus } \\
\text { Pullenia bulloides } \\
\text { Uvigerina proboscidea }\end{array}$ \\
\hline
\end{tabular}

\begin{tabular}{|c|c|c|c|c|c|c|}
\hline $\begin{array}{l}\text { Cancris sagra } \\
\text { Planulina exorna } \\
\text { Textularia agglutinans }\end{array}$ & $\begin{array}{l}\text { Cancriss sagra } \\
\text { Cibicoris inflatus } \\
\text { Epistominella bradyana }\end{array}$ & $\begin{array}{l}\text { Cibicorbis inflatus } \\
\text { Epistominella bradyana }\end{array}$ & $\begin{array}{l}\text { Epistominenlla smithi } \\
\text { Globocassidulina subglobosa } \\
\text { Psedoparrella exigua }\end{array}$ & $\begin{array}{l}\text { Epistominella bradyanc } \\
\text { Epistominella smithi } \\
\text { Lenticulina cushmani }\end{array}$ & $\begin{array}{l}\text { Uvigerina peregrina } \\
\text { Uvigerina proboscedea }\end{array}$ & $\begin{array}{l}\text { Oridorsalis umbonanatus } \\
\text { Pullenia bulloides } \\
\text { Uvigerina proboscidea }\end{array}$ \\
\hline
\end{tabular}




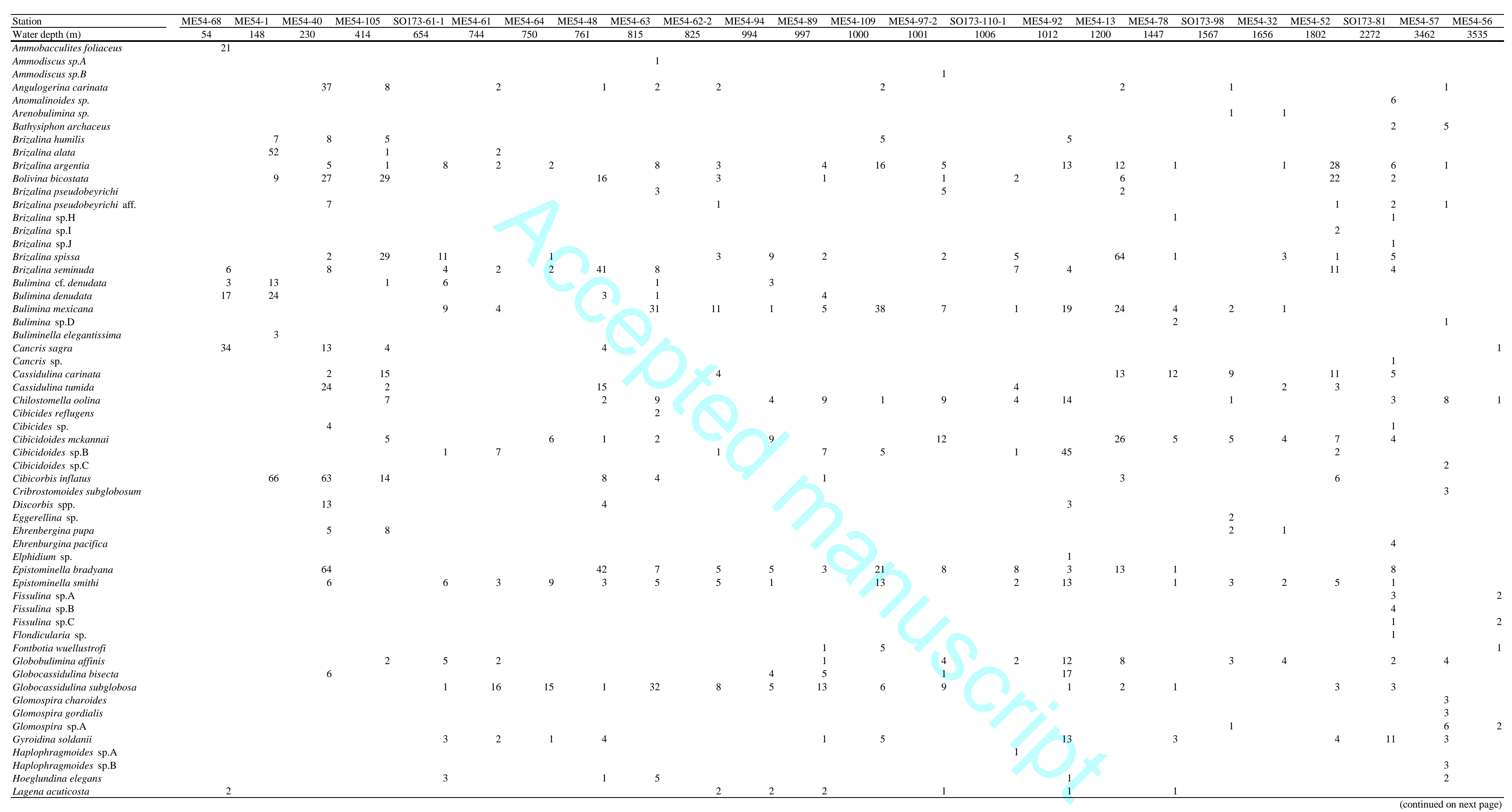




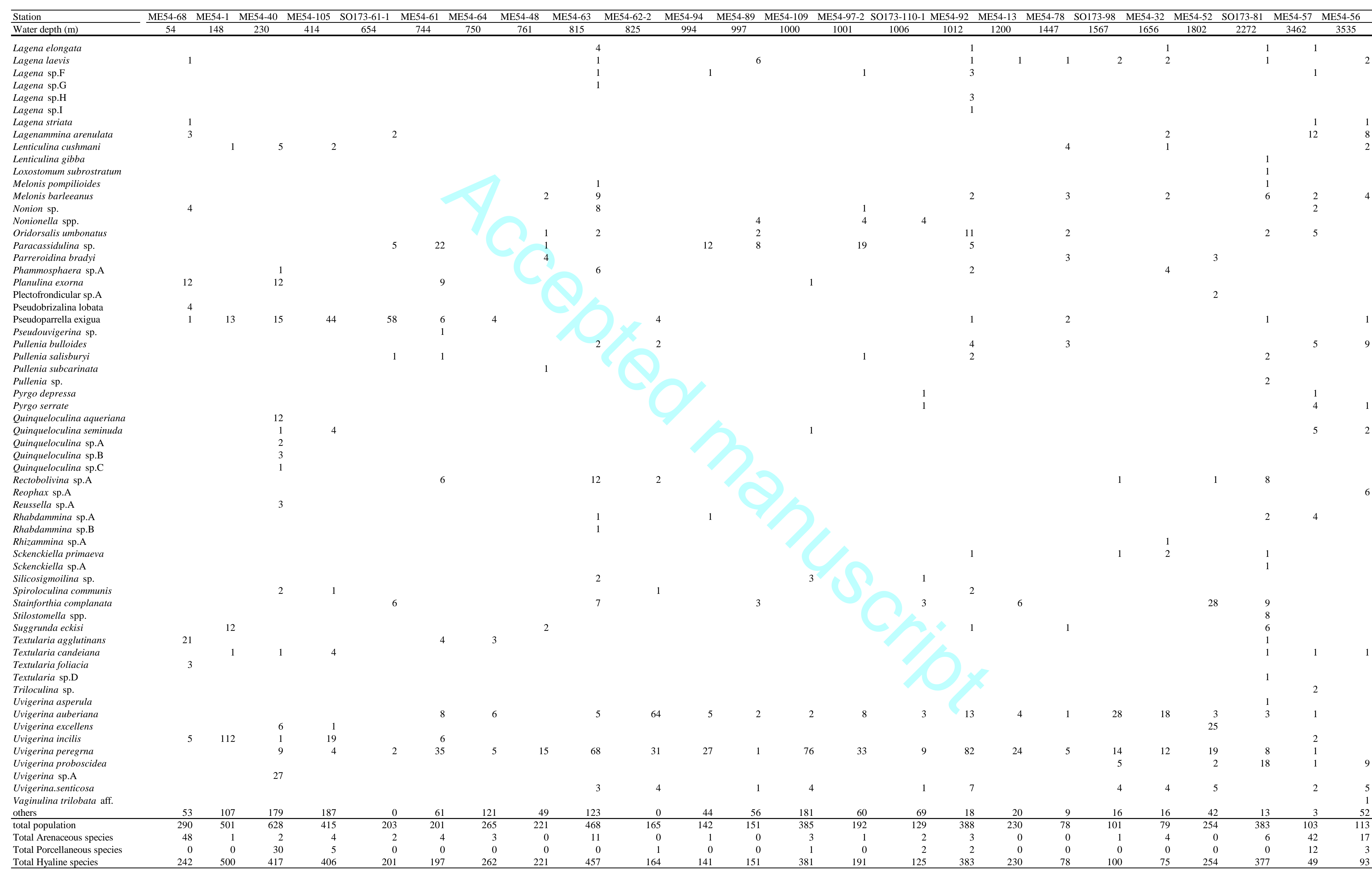

